\title{
AN INSTITUTIONAL PERSPECTIVE ON THE ADOPTION OF GREEN IS
}

\author{
\& IT ${ }^{1}$ \\ Adela J. Chen \\ Richard T. Watson \\ Marie-Claude Boudreau \\ Elena Karahanna \\ Department of Management Information Systems \\ Terry College of Business \\ University of Georgia \\ Athens, Georgia, USA
}

\begin{abstract}
This article examines how institutional pressures affect the adoption of green IS \& IT across organizations. From the natural-resource-based perspective, it examines green IS \& IT practices with strategic foci on pollution prevention, product stewardship, and sustainable development. Each category incorporates the separate roles played by IT (as a problem) and IS (as a solution). The partial least square method was employed to analyze the survey replies from 75 organizations. The results show that mimetic and coercive pressures significantly drive green IS \& IT adoption. In particular, outcomebased imitation and imposition-based coercion represent major institutional processes. The results also suggest the complementary relationship between mimetic and coercive pressures. Such interaction significantly motivates the green IS \& IT adoption focusing on product stewardship. These findings contribute to existing knowledge on the proenvironmental behaviors of organizations, demonstrate the interaction between institutional forces, and further current understanding of green IS \& IT adoption The study concludes with a general discussion of eco-goals and their relationship to institutional theory before considering the implications and directions for research and practice.
\end{abstract}

\section{INTRODUCTION}

Environmental sustainability has drawn significant interest among management researchers, as demonstrated by special issues in the Academy of Management Review (in 1995) and Academy of Management Journal (in 2000), and by targeted articles in specialized journals such as the Journal of Industrial Ecology, Journal of Environmental Management and Environmental Management. With a

${ }^{1}$ An earlier version of this paper was accepted by the International Conference on Information Systems (ICIS) in 2009. 
few exceptions (see Yi and Thomas, 2007, for a summary), however, researchers have neglected the role that information system (IS) and information technology (IT) have played in such endeavors (Watson et al. 2010; Chen et al. 2008). Indeed, much remains to be explored about the role played by IS \& IT in the worldwide pursuit of ecological sustainability. Such neglect may reinforce the implicit assumption that environmental sustainability lies outside of the IS research realm. Through this research, we seek to challenge this assumption by examining the adoption of green IS \& IT across organizations, and thus to inform practice and research about the role of IS and IT in the natural environment.

Although IS and IT are often used interchangeably, we clearly distinguish between them in our research. Whereas IT specifically focuses on devices that store, transmit, or process information, IS is more encompassing, as it includes the integrated and cooperating set of people, processes, software, and information technologies to support individual, organizational, or societal goals. As IS and IT are distinct with IS being more encompassing (Watson et al. 2010), we posit that IT and IS contribute to the environmental issues differently, For the most part, it appears that IT is part of the problem (e.g., data center's energy consumption, electronic waste, etc.) while IS can be part of the solution (e.g., environmental management systems, telecommuting programs, etc.) (Watson et al. 2009b; Boudreau et al. 2008).

An organization's decision to adopt green IS \& IT is often based on a complicated mix of both pragmatic (e.g., financial and legal) and idealist (e.g. moral and ethical) considerations (Lampe et al. 1991). On the one hand, green IS \& IT create financial concerns, as they may lead to reduced cost or incur additional expenses. Being green is not necessarily cost-efficient, though in many cases it is (e.g., Watson et al. 2009c). Green IS \& IT also have legal ramifications, as governments have started creating policies and regulations to penalize organizational waste and reward decrease in emissions. On the other hand, the "green" orientation also highlights the idealist implications of these technologies, both moral and ethical, as an organization's adoption may generate positive or negative consequences for others (Velasquez et al. 1985). Given the public-goods nature of the natural environment, organizational reactions to an environmental problem become a moral issue because of the potential to harm or benefit other stakeholders. It can also become an ethical issue for the same reasons (e.g., Jones 1991; Chan et al. 2008).

These idealist and pragmatic considerations relating to the adoption of green IS \& IT are not necessarily at odds, or conflicting, with one another. Indeed, the adoption of green IS \& IT has consequences for both the organization (e.g., impact on cost and productivity and legal fines) and others (e.g., moral and ethical impact on all stakeholders, including the natural environment and future generations).

This research leverages the institutional approach (DiMaggio et al. 1983) to better understand organizational adoption of green IS \& IT. The institutional perspective provides a useful theoretical lens to study the organizational response to environmental issues, because it understands that institutional forces beyond the market play a critical role in making organizations responsive to the interests of others (Scott 2003). In institutionalized organizations, legitimacy and efficiency do not necessarily co-vary (Zucker 1987). This is often true in the case of adopting green IS \& IT. Institutional theory explains how organizations adapt to institutional change through three different 
mechanisms - mimetic, normative, and coercive isomorphism ${ }^{2}$. The main effects of the three pressures are firmly defined. However, there are few studies investigating the interaction among them, which this study does. Particularly, this study focuses on the interaction between mimetic and coercive pressures.

The other major contribution is to inform the research and practice of green IS \& IT by reviewing the level of environmental friendliness of organizations in a wide range of practices. Understanding the adoption and diffusion of green IS \& IT across organizations informs the design of technological applications and institutional interventions to support ecological sustainability. The literature on green behaviors within organizations largely focuses on a single practice, such as recycling (Cheung et al. 1999). However, we believe that the level of an organization's environmental friendliness is better evaluated against a variety of relevant practices rather than a single one. Furthermore, reality requires that firms have a coherent portfolio of actions to enhance sustainability. Therefore, we adopt the natural-resource-based view of the firm (Hart 1995) to categorize organizational green IS \& IT practices into three groups based on their different strategic orientations, i.e., pollution prevention, product stewardship, and sustainable development. The three categories differ in terms of their resource requirements and contributions to ecological sustainability.

We surveyed 75 organizations to examine how institutional forces motivate organizational adoption of green IS \& IT. The results of our study provide an overview of the status quo of organizational green behaviors involving a variety of IS \& IT. This paper is structured as follows. First, we provide the necessary theoretical background (i.e., institutional theory and the natural-resource-based view) relevant to our research. Next, we present the research model, along with the propositions, and describe the indicators of the central constructs. After presenting and discussing the results, we conclude with implications for both research and practice.

\section{THEORETICAL BACKGROUND}

We draw upon institutional theory and the natural-resource-based view of the firm. Institutional theory explains how institutional isomorphism occurs through three different mechanisms - mimetic, coercive, and normative pressures. The natural-resource-based view of the firm differentiates among strategies that underlie different categories of green IS \& IT practices. We believe that the synergy of both theoretical perspectives yields a finely grained understanding of the effects of institutional pressures on organizational adoption of green IS \& IT.

\section{Institutional Theory}

Institutional theory provides a rich, complex view of how organizations become homogeneous in broad institutional environments, sometimes due to external sources, other times from within the organization. These include factors from the technical environment, such as economic performance, and various widely practiced sociological and cognitive elements, such as professional certification

\footnotetext{
${ }^{2}$ Mimetic isomorphism happens when organizations model other organizations' behaviors in pursuit of legitimacy or taken-for-granted practices. Normative isomorphism occurs when organizations feel compelled to honor certain cultural expectations from professional circles or the larger society. Coercive isomorphism is often driven by powerful stakeholders upon whom a focal organization depends.
} 
and prevalent activities across other organizations. Institutional theory has been used to explore an organization's environmental behaviors (Campbell 2007; Chen et al. 2008; Jennings et al. 1995).

By developing structures or taking actions that are isomorphic with institutional pressures, organizations gain legitimacy, resources, and survival capabilities (DiMaggio et al. 1983; Meyer et al. 1977). Institutional isomorphism is diffused through three mechanisms - normative, mimetic, and coercive isomorphism. The three mechanisms are not necessarily empirically distinguishable (DiMaggio et al. 1983; Mizruchi et al. 1999).

Compliance under normative pressures occurs when organizations feel compelled to honor certain cultural expectations from professional circles or the larger society. Normative pressures can diffuse through dyadic and multilateral relational channels. Mimetic isomorphism happens when organizations model other organizations' behaviors in pursuit of legitimacy or taken-for-granted practices (DiMaggio et al. 1983; Tolbert et al. 1983). When a clear course of action is not available to an organization, it might decide to mimic others. Coercive pressures are often associated with powerful actors upon whom a focal organization depends. There has been significant recognition of institutional forces as important predictors of the adoption and diffusion of IS products and practices (e.g., Liang et al. 2007; Orlikowski et al. 2001; Teo et al. 2003; Tingling et al. 2002). While many IS studies with an institutional perspective focus on a specific technology (such as electronic data interchange) with a direct bearing on adopters, we apply institutional theory to the adoption of a variety of IS \& IT practices with both pragmatic and moral implications.

\section{Natural-Resource-Based View of the Firm}

Organizational studies previously took little interest in the environment and focused on economic, social, political, and technological factors, with the natural environment being an absence of the performance puzzle (Shrivastava et al. 1992; Shrivastava et al. 1995). Recognizing the natural environment as an important emerging source of competitive advantage, Hart (1995) proposes a natural-resource-based view of the firm by integrating the natural environment into the resourcebased view. An organization's competitive advantage is built upon its capabilities to engage in green economic activities. From the natural-resource-based view, Hart (1995) distinguishes between three inter-connected green strategies with different orientations (Table 1).

\begin{tabular}{|c|c|c|}
\hline & Goals & Foci \\
\hline $\begin{array}{l}\text { Pollution } \\
\text { prevention }\end{array}$ & $\begin{array}{l}\text { To generate significant savings, } \\
\text { especially during early stages, resulting in } \\
\text { cost and productivity advantages over } \\
\text { other organizations (Hart et al. 1996). }\end{array}$ & $\begin{array}{l}\text { On reducing the cost of installing and } \\
\text { operating emission-control equipments } \\
\text { (Smart 1992), shortening cycle times } \\
\text { (Hammer et al. 1993), and reducing the } \\
\text { organization's compliance and liability } \\
\text { costs (Rooney 1993). }\end{array}$ \\
\hline $\begin{array}{l}\text { Product } \\
\text { stewardship }\end{array}$ & $\begin{array}{l}\text { To reduce the overall life-cycle } \\
\text { environmental costs of a product by } \\
\text { disciplining the design and development } \\
\text { process with the objective of (Shrivastava } \\
\text { et al. 1995). }\end{array}$ & $\begin{array}{l}\text { On mitigating the environmental } \\
\text { footprint of activities at each step of the } \\
\text { value chain and achieving system } \\
\text { transformation from cradle-to-grave to } \\
\text { cradle-to-cradle. }\end{array}$ \\
\hline $\begin{array}{l}\text { Sustainable } \\
\text { development }\end{array}$ & $\begin{array}{l}\text { To reduce the environmental impact of } \\
\text { organizational economic activities across } \\
\text { the world. }\end{array}$ & $\begin{array}{l}\text { On establishing long-term solutions } \\
\text { rather than short-term profits by } \\
\text { envisioning and developing clean } \\
\text { technologies (e.g., replacing synthetic } \\
\text { chemicals with biological substitutes). }\end{array}$ \\
\hline
\end{tabular}

Table 1. Three Green Strategies (Hart 1995) 


\section{Green IS \& IT}

Green IS \& IT refers to IS \& IT products (e.g., software that manages an organization's overall emissions) and practices (e.g., disposal of IT equipment in an environmentally friendly way) that aim to achieve pollution prevention, product stewardship, or sustainable development (Boudreau et al. 2008; Molla et al. 2009a). Green IS \& IT can play a critical role in enabling green business process management (Ghose et al. 2009) and in driving the shift to a sustainable society (Watson et al. 2009a). There is a growing awareness among professionals that IS \& IT can contribute to both the problem and the solution of environmental issues (Molla et al. 2009a). However, organizational investment in green IS \& IT is still at the early stage of maturity (Molla et al. 2009b), and such investment may take longer to yield a return (Olson 2008). Adoption and diffusion of green IS \& IT can be driven by a multitude of internal and external factors, such as financial, technological, organizational, regulatory, and ethical factors (González 2005; Kuo and Dick 2009; Molla 2008). This study conceptualizes and empirically assesses the impact of institutional factors on the adoption of green IS \& IT, recognizing that green IS \& IT can both be part of the problem and the solution.

\section{RESEARCH MODEL AND PROPOSITIONS}

This study focuses on the mimetic and coercive mechanisms of isomorphism. With the fervent concern for environmental issues in both academic and popular media, there is hardly any doubt about the existence of widespread consensus among members of organizational fields with respect to the necessity and urgency of green practices. Despite the lingering concern that environmentally friendly practices may erode competitiveness, the need of environmental protection is widespread because everyone wants a sustainably livable environment (Porter et al. 1995). Therefore, we propose that the foremost consideration in diffusing green practices is not how such diffusion is influenced by normative pressures, but how it is motivated through mimetic and coercive pressures when normative pressures are already established to some extent. Excluding normative pressure from this study allows us to eliminate a great amount of potential confounding, making the effects of mimetic and coercive pressures more likely to be detected. This decision is based on both theoretical and empirical considerations (see Table 2). By drawing upon institutional theory and the natural-resource-based view, we propose a research model including the main and the interaction effects of mimetic and coercive pressures on organizational adoption of green IS \& IT (see Figure 1).

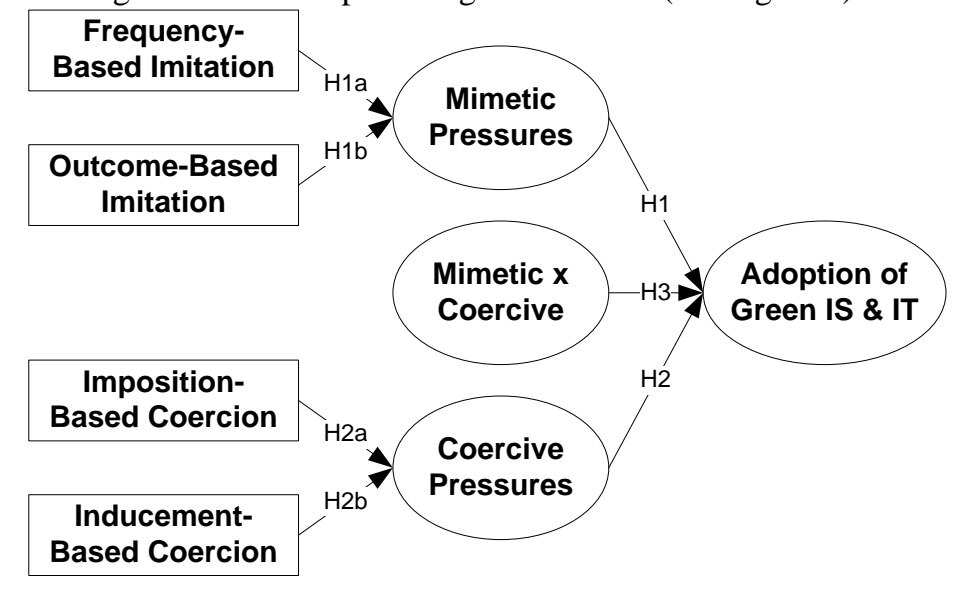

Figure 1. Research Model 


\begin{tabular}{|l|l|l|}
\hline $\begin{array}{l}\text { Sources of Normative } \\
\text { Pressure }\end{array}$ & Theoretical Consideration & Empirical Consideration \\
\hline $\begin{array}{l}\text { Suppliers and } \\
\text { Customers (Dyadic } \\
\text { relational channel) }\end{array}$ & $\begin{array}{l}\text { Given the generic nature of green behaviors of } \\
\text { interest to this study, suppliers and customers } \\
\text { become a source of mimetic pressure at the same } \\
\text { time. }\end{array}$ & $\begin{array}{l}\text { The same scale, namely, the } \\
\text { extent of adoption, measures } \\
\text { both pressures in the literature. }\end{array}$ \\
\hline $\begin{array}{l}\text { Professional Affiliation } \\
\text { (Multilateral relational } \\
\text { channel) }\end{array}$ & $\begin{array}{l}\text { Accumulation of normative pressure from } \\
\text { professional affiliation can heighten environmental } \\
\text { issues, resulting in coercion such as public policies. }\end{array}$ & $\begin{array}{l}\text { The temporal sequence will be } \\
\text { masked by correlation in a } \\
\text { cross-sectional study. }\end{array}$ \\
\hline
\end{tabular}

Table 2. Potential Confounding of Normative Pressure with Mimetic and Coercive Pressures

\section{Mimetic Pressures}

Mimetic isomorphism is considered a standard organizational response to uncertainty when the course of action is unclear (DiMaggio et al. 1983). The adoption of green IS \& IT often involves considerable uncertainty. Deviation from the single bottom line of profitability requires a mindset shift among managers and induces uncertainty. Addressing the moral component of environmental issues while maximizing profitability represents a new challenge for practitioners. The moral component of an environmental issue can be converted into one that incurs instrumental consideration through the enforcement of regulations or industrial standards. Relentless punishment such as steep fines or suspension of operation licenses for dumping industrial waste and toxic carries an immediate monetary implication for organizations that violate the mandate. In the absence of such coercive forces, other organizations' behaviors and the corresponding outcomes play a critical role in determining an organization's decision with respect to a moral issue. Mimetic isomorphism as an organization's strategic response to uncertainty has been observed in diverse studies, such as the adoption of a certain organizational form (Lee et al. 2002) and the diffusion of automated teller machines prior to the establishment of its business value (Banker et al. 1988).

\section{P1: Mimetic pressures will be positively related to the adoption of green IS \& IT.}

The two fundamental modes of imitation of interest here are frequency- and outcome-based imitations (Haunschild et al. 1997). Frequency-based mimetic pressure arises from the number of other organizations that have adopted a certain practice. With outcome-based imitation, organizations are motivated to adopt a given practice because of the favorable results achieved by other adopters. With trait-based imitation, organizations mimic the behaviors of other organizations with whom they share important attributes.

\section{Frequency-Based Imitation}

When driven by frequency-based mimetic pressures, organizations make adoption decisions based on the prevalence of a practice. Frequency-based imitation is considered the purest form of mimetic isomorphism, as all organizations in a focal organization's institutional context have the same effects on its decision-making ( $\mathrm{Lu}$ 2002). On the one hand, such prevalence is strong evidence of the legitimacy of the practice. When a practice has been adopted by a growing number of organizations, it becomes increasingly taken-for-granted so that some organizations may adopt such practice without thinking (March 1981; Zucker 1977). On the other hand, a frequently adopted practice can become difficult to change and reduce the likelihood of alternatives through the imprinting process (Mezias 1990). In the face of high uncertainty associated with adopting green IS \& IT, the sheer number of adopters in an organization's institutional context provides the decision base, indicating the 
desirability of a given green IS \& IT. Past research has shown that an organization's likelihood of adopting a given practice is positively related to the proportion of prior adoption by other organizations (e.g., Burns et al. 1993; Haunschild et al. 1997)

Pla: Frequency-based imitation will be positively related to the adoption of green IS \& IT.

\section{Outcome-Based Imitation}

When outcome-based pressures are at play, organizations tend to imitate others when the observed consequences of implementing these practices are considered favorable. Unlike the frequency-based imitation, outcome-based imitation is considered a selective process of mimetic isomorphism (Lu 2002). The lack of immediate economic gains represents a barrier to organizational adoption of green IS \& IT. Therefore, it is difficult for such practices to be immediately accepted by organizations, especially the myopic profit-focused ones. When this is the case, the adoption outcomes of other organizations will greatly reduce the search costs and the uncertainty faced by a potential adopter, leading to adoption (or non-adoption) decisions. An organization looks to the success or failure of other adopters in its decision-making. Outcome-based imitation has been observed in various settings, such as market entry mode (Lu 2002) and investment banker choice (Haunschild et al. 1997).

\section{P1b: Outcome-based imitation will be positively related to the adoption of green IS \& IT.}

\section{Coercive Pressures}

Coercive isomorphism is driven by both formal and informal forces exerted by other organizations, upon which an organization relies (DiMaggio et al. 1983). From a resource-dependence perspective, coercive pressures arise from the exchange relationship between an organization and others, which may include regulatory institutions, funding bodies, and resource-dominant organizations. Given the institutionalized pattern of dependency (e.g., regulations, policies, contracts, and formal programs), a resource-dependent organization complies with the resource-dominant organization to sustain the exchange relationship and secure its own survival (Pfeffer et al. 1978). An organization's adoption of green practices arises from both regulatory bodies and important supply chain partners through imposition and inducement respectively.

\section{P2: Coercive pressures will be positively related to the adoption of green IS \& IT.}

\section{Imposition-Based Coercion}

The adoption of green practices may be imposed upon organizations, as when regulatory authorities such as governments or agencies mandate such behaviors by law or industrial standards. Regulatory institutions utilize coercive power to create institutional elements when they perceive that organizational practices are in conflict with the societal good. With regulatory authority, these institutional elements, such as industrial regulations and threat of legal sanctions, are powerful tools to govern organizational behaviors. The consequences for noncompliance may include suspension of an operating license or a steep monetary penalty. Coercion in the form of public policy plays an important role in effective environmental management (Kilbourne et al. 2002). In the US, regulatory institutions have enacted ordinances, regulations and laws in response to the growing awareness of 
environmental issues (Clemens et al. 2006). Imposition-based coercion has been the most prevalent approach in the US (Delmas and Terlaak, 2001). The mandate of the low emission vehicle by the Californian Air Resources Board has stimulated active investment in R\&D across automobile manufacturers (Frenken et al. 2004).

\section{P2a: Imposition-based coercion will be positively related to the adoption of green IS \& IT.}

\section{Inducement-Based Coercion}

The second manner in which coercive isomorphism may happen is that of inducements when supply chain partners make the fulfillment of certain criteria an eligibility requirement for collaboration. An organization may develop the dependence on certain customers and suppliers when these organizations account for most of its sales and purchases, and are hard to be replaced by others. Important supply chain partners do not have the authority or power to impose regulations or laws, but they often possess the power to create strong inducements for a focal organization to comply with their demands (Meyer et al. 1992). Supply chain partners generate forces for conformity to certain standards, which translate into coercive pressure by providing incentives (or disincentives). They can specify the conditions for the receipt of future contracts or ongoing collaboration. Resource-dominant organizations that have adopted green IS \& IT may influence their supply chain partners to behave in an environmentally friendly way as well in order to reap more benefits from their own adoption. For example, important customer or supply chain partners, as "dominant" or "definitive" stakeholders (Mitchell et al. 1997), may exert pressures over organizations to be certified to ISO 14000, which entails guidelines for different aspects of environmental management. Wal-Mart has successfully reduced the shipping cost through persuading its suppliers to reduce packaging and increase product concentration. Despite its lack of regulatory power, Wal-Mart drives the adoption of environmentally friendly packaging among its suppliers who aim to retain the business exchange. In the context of adopting green IS \& IT, an organization can be subject to the pressures from its supply chain partners that have adopted green IS \& IT and attempt to maximize the financial (e.g., cost reduction) and social (e.g., reputation of being environmentally responsible) benefits of the adoption.

Funding decisions by stakeholders with added requirements fall within the purview of inducementbased coercion. Some individuals and organizations behave in an environmentally friendly way in order to win funding opportunities, given the growth in funding on innovations that address environmental issues. Environmental Defense Fund has induced a number of organizations to reduce emissions and heavily polluting materials with financial support and allowances (Bonifant et al. 1994).

\section{P2b: Inducement-based coercion will be positively related to the adoption of green IS \& IT.}

\section{Interaction between Mimetic and Coercive Pressures}

Both mimetic and coercive pressures aim at motivating institutional isomorphism. However, they trigger different reasoning mechanisms behind an organization's decisions to adopt green practices. On the one hand, coercive isomorphism is an organization's conforming response to mandated standards. Under coercive pressures, the threat of sanction by powerful organizations such as regulatory authorities and critical supply chain partners drives an organization's adoption choices. On the other hand, mimetic isomorphism represents an organization's response to uncertainty as a barrier to adoption of green practices. With mimetic pressure, organizations use the frequency and outcome of others' adoption as a proxy indicator of the legitimacy of a given practice, when there is lack of 
adequate information to validate the feasibility and profitability of such a practice through a cost-andbenefit calculation.

The institutional pressures do not necessarily operate in isolation, especially in a dynamic environment (Roy et al. 2000). Between coercive and mimetic pressures, the presence of one is very likely to add to the institutional legitimacy suggested by the other. In organizational fields where coercive pressure is not directly involved, mimetic forces represent a significant factor in an organization's green decision-making (Jennings et al. 1995). The prevalence of a green practice among organizations may reflect the urgency and validity of existing or anticipated coercive forces. Legal enforcement of a regulation or pressures from supply chain partners may suggest the legitimacy and criticality of a green practice, easing the uncertain conditions faced by potential adopters. Moreover, when evidence of the value of a given practice comes from multiple sources rather than a single one, it is very likely to be perceived as more convincing by an organization. Therefore, the presence of one pressure reinforces the effect of the other. We expect mimetic and coercive pressures to synergistically combine, lowering the uncertainty faced by potential adopters of green IS \& IT and demonstrating the regulatory validity.

\section{P3: Interaction between coercive and mimetic pressures will have a positive effect on the adoption of green IS \& IT.}

\section{Controls}

Organizations are subject to different regulatory sanctions across industries. For example, the food and drug industries are more tightly regulated than textile manufacturing because of the public health consequences. Therefore, we include industry as a control variable. Financial resources are an important precursor to innovation adoption (Iacovou et al. 1995; Riggins et al. 1994). Organizations with sufficient financial resources are able to experiment with new practices and cope with adoption failures. As a result, revenue is also included as a control.

\section{METHODOLOGY}

A questionnaire-based, cross-sectional field study was conducted to test the research model, as the objective of this research is to understand the effects of institutional pressures on the adoption of green IS \& IT by organizations. Data were collected through the Cutter Consortium in 2008. The total sample size was 75 participating organizations, which were from 18 industries, including both manufacturing and service industries, and from 22 countries, with about one third of the sample in the U.S. Of the 75 responding organizations, $37 \%$ are headquartered or based in North America, $28 \%$ in Europe, 24\% in Asia/Australia/Pacific, and the remainder in other regions. Of these organizations, $12 \%$ have over 50000 employees, $16 \%$ have between 5000 and 50000 employees, $17 \%$ have between 1000 and 5000 employees, 29\% have between 100 and 1000 employees, and the remainder have no more than 100 employees. The majority of the organizational representatives who filled out the questionnaires were in a position of IS management (26.7\%), consulting (21.3\%), or senior management/policymaking (14.7\%). We aimed to examine general rather than industry-specific green IS \& IT adopted by organizations. Therefore, our target population consisted of organizations across industries and with diverse attributes (see Table 3). 


\begin{tabular}{|l|l|l|l|}
\hline $\begin{array}{l}\text { Annual Revenues of } \\
\text { Organizations/Divisions (US \$) }\end{array}$ & $\begin{array}{l}\text { Response } \\
\text { Percentage }\end{array}$ & $\begin{array}{l}\text { Annual Revenues of } \\
\text { Organizations/Divisions (US \$) }\end{array}$ & $\begin{array}{l}\text { Response } \\
\text { Percentage }\end{array}$ \\
\hline Less than 1 million & $25.3 \%$ & $\begin{array}{l}\text { More than 100 million to 1 } \\
\text { billion }\end{array}$ & $18.7 \%$ \\
\hline 1 million to 10 million & $12 \%$ & More than 1 billion to 10 billion & $13.3 \%$ \\
\hline More than 10 million to 50 million & $12 \%$ & $\begin{array}{l}\text { More than 10 billion to 50 } \\
\text { billion }\end{array}$ & $5.3 \%$ \\
\hline $\begin{array}{l}\text { More than 50 million to 100 } \\
\text { million }\end{array}$ & $10.7 \%$ & More than 50 billion & $2.7 \%$ \\
\hline
\end{tabular}

Table 3. Annual Revenue of Organizations/Divisions

\section{Operationalization}

All the dependent and independent variables were operationalized formatively, according to the Jarvis et al. (2003) criteria. The measures are summarized in Table 4.

\section{Dependent Variables}

Based on empirical studies of green IT practices (such as telecommuting), on interviews with professional and managerial employees, and on discussions with colleagues interested in green IS \& IT, we generated the items tapping each of the categories discussed in the preceding theoretical background: green IS \& IT practices focusing on pollution prevention, product stewardship and sustainable development. Thus, we operationalized organizational adoption of green IS \& IT through three dependent variables. For item clarity, we retained the distinction between the separate roles played by IS \& IT, as both a problem and a solution. The items themselves did not combine both aspects, each with a single focus either on practices to curb the environmental impact of IT or on practices enabled by IS to enhance the environmental friendliness of other business operations. This distinction is important because it allows an explicit empirical investigation of the seemingly contradictory roles in environmental issues. Thus, the three dependent variables are measured formatively, each with two dimensions capturing the roles played by IS \& IT. This study examines a wide variety of green IS \& IT practices, which may differ from each other along multiple dimensions. For example, they range from low-frequency practices such as investing in energy-efficient IT hardware and software to high-frequency ones such as using green IS to manage overall emissions. Moreover, they include both intra-organizational practices such as using renewable energy to support IT infrastructure to inter-organizational practices such as enhancing the environmental friendliness of supply chain activities through green IS. Given the diversified nature of the green IS \& IT practices, we used the level of institutionalization (i.e., the existence of policies/regulations/incentives) of such practices as a proxy of adoption. This measure, as opposed to the traditional adoption measures (e.g., frequency and scope), captures the stabilized organizational behaviors. Each item asked respondents to indicate the adoption status of their organizations on a 3-point Likert scale, with 1 representing no adoption, 2 representing adoption plan, and 3 representing existing adoption.

Dependent variables - adoptions of green IS \& IT with a focus on pollution prevention, product stewardship, and sustainable development - are each measured with two formative indicators, with the first indicator addressing IT as a cause of the environmental issues and the second indicator presenting IS as a solution of environmental issues (Table 4).

\section{Independent and Control Variables}

Mimetic and coercive pressures were both measured formatively with scales adapted from Teo, Wei and Benbasat's study (2003). Each scale asked respondents to indicate the degree to which they 
agreed with the statements regarding the institutional pressures on a 5-point Likert format, with 1 representing strongly disagree and 5 representing strongly agree.

Mimetic Pressure. We measured mimetic pressure through two formative indicators: frequency- and outcome-based mimetic forces. To measure the former, we used the mean of two reflective indicators capturing the extent of adoptions by an organization's competitors and supply chain partners. To measure the latter, we used the mean of four reflective indicators that capture the perceived success of adoptions by other organizations.

Coercive Pressure. We measured coercive pressure through two formative indicators: imposition- and inducement-based coercive pressures. We measured the former by asking respondents to indicate whether their organizations are pressured to adopt green IS \& IT by current and foreseeable regulations. Two reflective indicators on whether the organizations are pressured to adopt green IS \& IT by major customers and suppliers were used to gauge the latter.

Control Variables. For the control variables (i.e., industry and revenue), we used two ordinal variables that indicate the industry and revenue range of an organization respectively.

\section{DATA ANALYSIS}

We used the partial least squares (PLS), a variance-based structural equation modeling (SEM) tool, to test the research model in view of PLS's ability to operationalize a latent construct either formatively or reflectively. We adopted SmartPLS with a 500 sample bootstrapping technique for model assessment. All statistical tests were assessed with one-tailed t-tests because of the unidirectional nature of our hypotheses and corollaries.

An important concern for formative indicators is multicollinearity (Diamantopoulos et al. 2001; Petter et al. 2007). Since Mimetic Pressure and Coercive Pressure are formatively measured, we examined Variance Inflation Factors (VIF). With the maximum VIF being 1.495 , neither exceeds 3.3 as recommended by Diamantopoulos and Siguaw (2006). This indicates that multicollinearity is not a concern. The inter-construct correlations for the second-order constructs are presented in Table 5 and the correlations between the first-order dimensions (as well as control variables) are shown in Appendix A. We assessed the correlations among the formative dimensions of the institutional pressures. The extent of adoption by supply chain partners, as one dimension of the normative pressure in the literature, is significantly and highly correlated $(>=0.6)$ with the extent of adoption by competitors, as one dimension of the mimetic pressure. Professional affiliation, as the other dimension of the normative pressure in the literature, is significantly and highly correlated $(>=0.6)$ with both imposition- and inducement-based coercive pressures. The results support our rationale for excluding the normative pressure from this study. Prior to assessing the structural model, we assessed the psychometric properties of our first-order dimensions. Factor analysis (see Table 6), comparison of the average variance extracted (AVE) to inter-construct correlations (see Appendix A), and reliabilities (see Table 4) show that our scales exhibit good psychometric properties. 


\begin{tabular}{|c|c|c|}
\hline Constructs & Measure (Reliability) & Items \\
\hline \multirow[t]{2}{*}{$\begin{array}{l}\text { Mimetic } \\
\text { Pressure }\end{array}$} & $\begin{array}{l}\text { Frequency-based imitation: Extent } \\
\text { of adoption by competitors, } \\
\text { suppliers and customers }(0.820)\end{array}$ & $\begin{array}{l}\text { What is the current extent of the adoption of sustainable IS business } \\
\text { practices by your organization's competitors (Adp_Comp)? supply chain } \\
\text { ecosystem (Adp_SuCu)? }\end{array}$ \\
\hline & $\begin{array}{l}\text { Outcome-based imitation: } \\
\text { Perceived success of competitors, } \\
\text { suppliers and customers that have } \\
\text { adopted green IS \& IT }(0.852)\end{array}$ & $\begin{array}{l}\text { - Our main competitors who have adopted sustainable IS business } \\
\text { practices } \\
\circ \text { have benefited greatly financially. (Suc_C1) } \\
\circ \text { are perceived favorably by customers. (Suc_C2) } \\
\text { Within my organization's supply chain management ecosystem, } \\
\text { those who have adopted sustainable IS business practices } \\
\circ \text { have benefited greatly financially. (Suc_SuCu1) } \\
\circ \text { are perceived favorably by customers. (Suc_SuCu2) }\end{array}$ \\
\hline \multirow[t]{2}{*}{$\begin{array}{l}\text { Coercive } \\
\text { Pressure } \\
\end{array}$} & $\begin{array}{l}\text { Imposition-based coercion: } \\
\text { Pressure from regulatory bodies }\end{array}$ & $\begin{array}{l}\text { Current and foreseeable regulations are pressuring us to adopt } \\
\text { sustainable IS business practices. (Policy) }\end{array}$ \\
\hline & $\begin{array}{l}\text { Inducement-based coercion: } \\
\text { Pressure from major customers } \\
\text { and suppliers }(0.801)\end{array}$ & $\begin{array}{l}\text { - Our suppliers are pressuring us to adopt sustainable IS business } \\
\text { practices. (Press_Sup) } \\
\text { Our major customers are pressuring us to adopt sustainable IS } \\
\text { business practices. (Press_Cus) }\end{array}$ \\
\hline \multirow[t]{2}{*}{$\begin{array}{l}\text { Pollution } \\
\text { Prevention }\end{array}$} & $\begin{array}{l}\text { PolPre_prob: Organizational } \\
\text { action on reducing energy } \\
\text { consumed by IT infrastructure and } \\
\text { hardware (IT as a problem) }\end{array}$ & $\begin{array}{l}\text { To what extent does your organization have policies } \\
\text { - } \quad \text { to reduce the energy consumed by its IT infrastructure (through } \\
\text { virtualization, thin clients, etc.)? } \\
\text { to purchase energy-efficient IT hardware (e.g., Energy Star, } 80 \\
\text { PLUS power supply, Electronic Product Environmental assessment } \\
\text { Tool, etc.)? }\end{array}$ \\
\hline & $\begin{array}{l}\text { PolPre_solu: Organizational } \\
\text { adoption of IS to reduce overall } \\
\text { emissions, waste and hazardous } \\
\text { materials (IS as a solution) }\end{array}$ & $\begin{array}{l}\text { To what extent does your organization have policies that encourage } \\
\text { installation of software for which the main goal is to reduce your } \\
\text { organization's overall emissions? waste? use of hazardous and toxic } \\
\text { materials? }\end{array}$ \\
\hline \multirow[t]{2}{*}{$\begin{array}{l}\text { Product } \\
\text { Stewardship }\end{array}$} & $\begin{array}{l}\text { ProSte_prob: Organizational } \\
\text { action on disposing of IT } \\
\text { equipment in an environmentally } \\
\text { friendly way (IT as a problem) }\end{array}$ & $\begin{array}{l}\text { To what extent does your organization have policies that encourage } \\
\text { - } \quad \text { purchasing products based on an IT vendor's end-of-life/recycling } \\
\text { program? (ProSte2) } \\
\text { disposing of its IT equipment in an environmentally friendly } \\
\text { manner? (ProSte3) }\end{array}$ \\
\hline & $\begin{array}{l}\text { ProSte_solu: Organizational } \\
\text { adoption of IS to enhance the } \\
\text { environmental friendliness of } \\
\text { upstream and downstream supply } \\
\text { chain management (IS as a } \\
\text { solution) }\end{array}$ & $\begin{array}{l}\text { To what extent does your organization have policies that encourage } \\
\text { installing software for which the main goal is } \\
\text { - to make its upstream supply chain management (material sourcing } \\
\text { and acquisition) more environmentally friendly? } \\
\text { to make its downstream supply chain management (product } \\
\text { distribution and delivery) more environmentally friendly? }\end{array}$ \\
\hline \multirow[t]{2}{*}{$\begin{array}{l}\text { Sustainable } \\
\text { Development }\end{array}$} & $\begin{array}{l}\text { SusDev_prob: Organizational } \\
\text { action on seeking renewable } \\
\text { energy to support IT infrastructure }\end{array}$ & $\begin{array}{l}\text { To what extent does your organization have policies that encourage use } \\
\text { of renewable energy (solar, wind, hydro, etc.) to support its IT } \\
\text { infrastructure? }\end{array}$ \\
\hline & $\begin{array}{l}\text { SusDev_solu: Organizational } \\
\text { adoption of IS to transform } \\
\text { business operations (IS as a } \\
\text { solution) }\end{array}$ & $\begin{array}{l}\text { To what extent does your organization have policies that encourage } \\
\text { - online collaboration tools (beyond email) to substitute for travel } \\
\text { (e.g., video conferencing, etc.)? } \\
\text { - } \quad \text { employee telecommuting? } \\
\text { transforming its business processes to be paperless? }\end{array}$ \\
\hline
\end{tabular}

Table 4. Operationalization of Constructs 


\begin{tabular}{|l|l|l|l|}
\hline & Coercive Pressures & Mimetic Pressures & Pollution prevention \\
\hline Coercive Pressures & 1.000 & & \\
\hline Mimetic Pressures & 0.488 & 1.000 & \\
\hline Pollution prevention & 0.502 & 0.527 & 1.000 \\
\hline & Coercive Pressures & Mimetic Pressures & Product Stewardship \\
\hline Coercive Pressures & 1.000 & & \\
\hline Mimetic Pressures & 0.455 & 1.000 & \\
\hline Product Stewardship & 0.476 & 0.450 & 1.000 \\
\hline & Coercive Pressures & Mimetic Pressures & Sustainable development \\
\hline Coercive Pressures & 1.000 & & \\
\hline Mimetic Pressures & 0.487 & 1.000 & \\
\hline Sustainable Development & 0.422 & 0.462 & 1.000 \\
\hline
\end{tabular}

Table 5. Intercorrelations Among Latent Variables

\begin{tabular}{|l|l|l|l|l|l|l|l|l|l|l|l|l|l|l|}
\hline & \multicolumn{3}{|l}{ Pollution Prevention } & \multicolumn{4}{l|}{ Product Stewardship } & \multicolumn{3}{l|}{ Sustainable Development } \\
\cline { 2 - 14 } & $(1)$ & $(2)$ & $(3)$ & $(4)$ & $(1)$ & $(2)$ & $(3)$ & $(4)$ & $(1)$ & $(2)$ & $(3)$ & $(4)$ \\
\hline $\begin{array}{l}\text { Adp_Com } \\
\text { p }\end{array}$ & 0.87 & 0.161 & 0.086 & 0.038 & 0.884 & 0.178 & 0.086 & 0.04 & 0.813 & 0.181 & 0.086 & 0.037 \\
\hline $\begin{array}{l}\text { Adp_SuC } \\
\text { u }\end{array}$ & 0.959 & 0.216 & 0.054 & 0.175 & 0.95 & 0.222 & 0.054 & 0.171 & 0.984 & 0.216 & 0.054 & 0.177 \\
\hline Suc_C1 & 0.119 & 0.853 & 0.335 & 0.411 & 0.122 & 0.873 & 0.335 & 0.404 & 0.106 & 0.897 & 0.335 & 0.416 \\
\hline Suc_C2 & 0.105 & 0.834 & 0.299 & 0.287 & 0.099 & 0.8 & 0.299 & 0.271 & 0.123 & 0.79 & 0.299 & 0.298 \\
\hline $\begin{array}{l}\text { Suc_SuC } \\
\text { u1 }\end{array}$ & 0.307 & 0.859 & 0.388 & 0.461 & 0.306 & 0.889 & 0.388 & 0.451 & 0.307 & 0.9 & 0.388 & 0.467 \\
\hline $\begin{array}{l}\text { Suc_SuC } \\
\text { u2 }\end{array}$ & 0.174 & 0.781 & 0.486 & 0.384 & 0.172 & 0.756 & 0.486 & 0.377 & 0.179 & 0.708 & 0.486 & 0.389 \\
\hline & 0.003 & 0.45 & 1 & 0.585 & 0.002 & 0.448 & 1 & 0.575 & 0.022 & 0.432 & 1 & 0.59 \\
\hline Policy & 0.136 & 0.502 & 0.598 & 0.935 & 0.131 & 0.508 & 0.598 & 0.913 & 0.155 & 0.505 & 0.598 & 0.95 \\
\hline Press_Cus & 0.106 & 0.32 & 0.454 & 0.889 & 0.103 & 0.332 & 0.454 & 0.914 & 0.116 & 0.33 & 0.454 & 0.868 \\
\hline Press_Sup
\end{tabular}

(1) - Frequency-Based Imitation, (2) - Outcome-Based Imitation, (3) - Imposition-Based Coercion, (4) - Inducement-Based Coercion

\section{Table 6. PLS Confirmatory Factor Analysis Results}

As shown in Figure 2, Figure 3, and Figure 4, PLS results provide strong support for H1 and H2. The lines marked with an asterisk represent the paths that are significant at 0.05 . The corollary H1b is consistently supported across the models, indicating strong evidence for the role of outcome-based pressure in organizational adoption of green IS \& IT. The corollary H1a is not supported in all models. Hypotheses $\mathrm{H} 2 \mathrm{a}, \mathrm{H} 2 \mathrm{~b}$ and $\mathrm{H} 3$ are partially supported. Mimetic and coercive pressures, but not the control variables (i.e., industry and revenue), are significant determinants of organizational adoption of green IS \& IT, explaining $35.6 \%, 29.7 \%$, and $27.6 \%$ of the variances in practices focusing on pollution prevention, product stewardship and sustainable development, respectively. We first ran these models including the control variables one at a time. Because neither of them is significant at 0.05, we exclude the control variables from the models presented in this paper. Furthermore, all formative indicators of the dependent variables, except for the "IT as a problem" dimension of sustainable development, have significant weights on their corresponding constructs. Table 7 and Figure 5 show the results of our tests of the interaction hypotheses. The hypothesized complementary 
effect (i.e., positive interaction) between mimetic and coercive pressures is significant only in the product stewardship model. The interaction effects, which are presented in Figure 6, explain an additional $6.8 \%$ of variance in the adoption of green IS \& IT focusing on product stewardship.

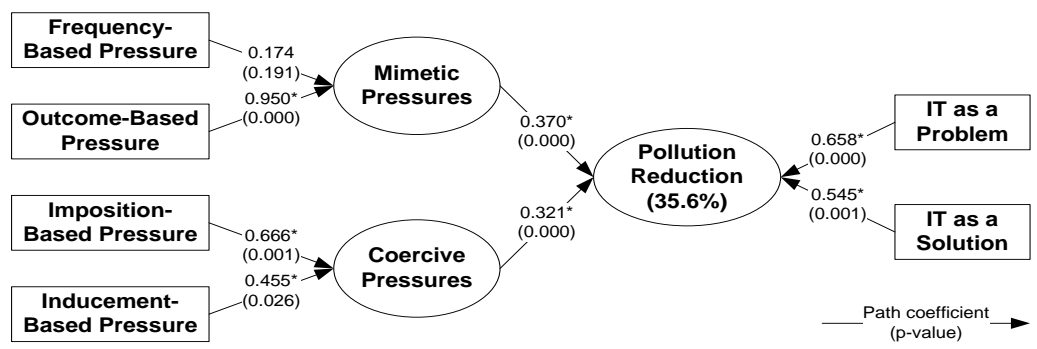

Figure 2. PLS Results (pollution prevention

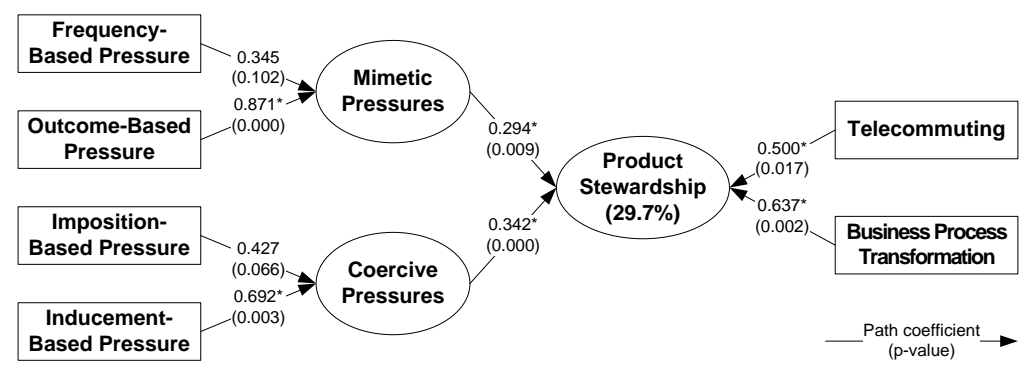

Figure 3. PLS Results (product stewardship)

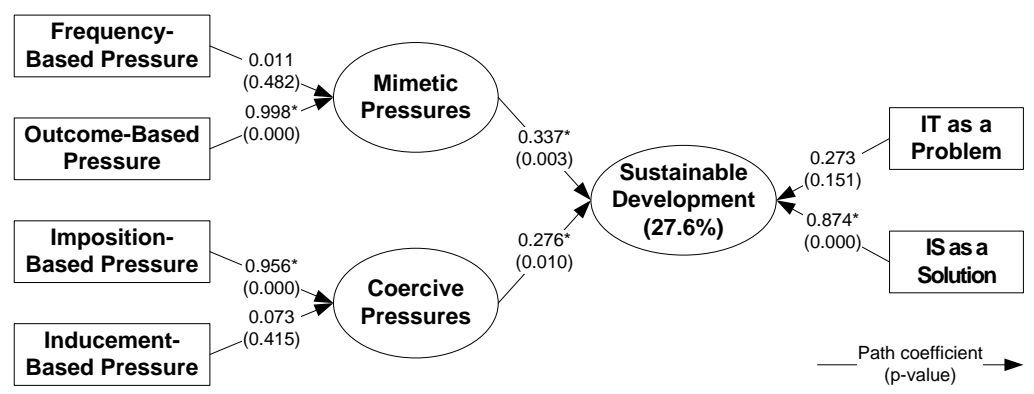

Figure 4. PLS Results (sustainable development)

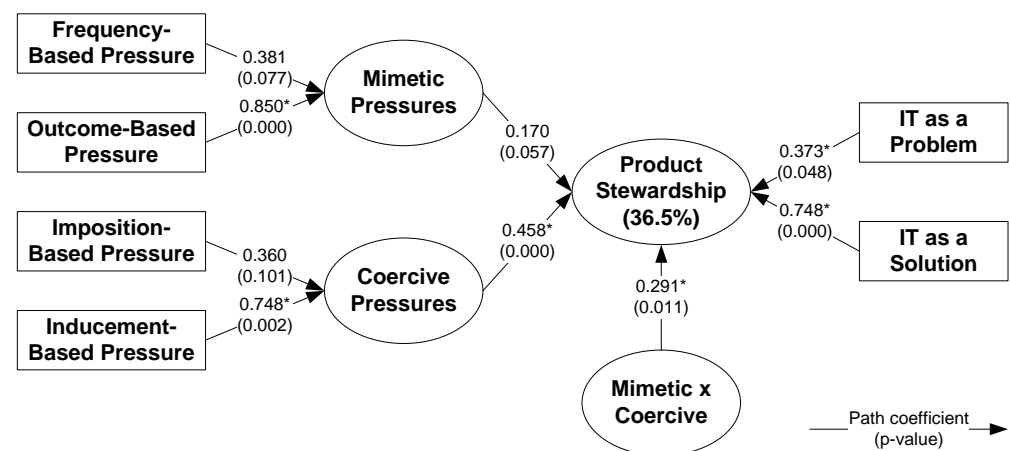

Figure 5. PLS Results (product stewardship with interaction effect) 


\begin{tabular}{|l|l|l|}
\hline Independent Variable & Model 1 & Model 2 \\
\hline Mimetic Pressures $\rightarrow$ Product Stewardship & $\begin{array}{l}0.294^{*} \\
(0.009)\end{array}$ & $\begin{array}{l}0.170 \\
(0.057)\end{array}$ \\
\hline Coercive Pressures $\rightarrow$ Product Stewardship & $\begin{array}{l}0.342^{* *} \\
(0.000)\end{array}$ & $\begin{array}{l}0.458^{* *} \\
(0.000)\end{array}$ \\
\hline $\begin{array}{l}\text { Mimetic Pressures x Coercive Pressures } \rightarrow \text { Product } \\
\text { Stewardship }\end{array}$ & & $\begin{array}{l}0.291^{*} \\
(0.011)\end{array}$ \\
\hline Adjusted R $\mathrm{R}^{2}$ & $29.70 \%$ & $36.50 \%$ \\
\hline$\Delta \mathrm{R}^{2}$ & & $6.80 \%$ \\
\hline$F$ & & $7.603 *$ \\
\hline
\end{tabular}

Table 7. Interaction Effects for Product Stewardship (p-value** $\boldsymbol{p}<\mathbf{0 . 0 0 1} * \boldsymbol{p}<\mathbf{0 . 0 1})$

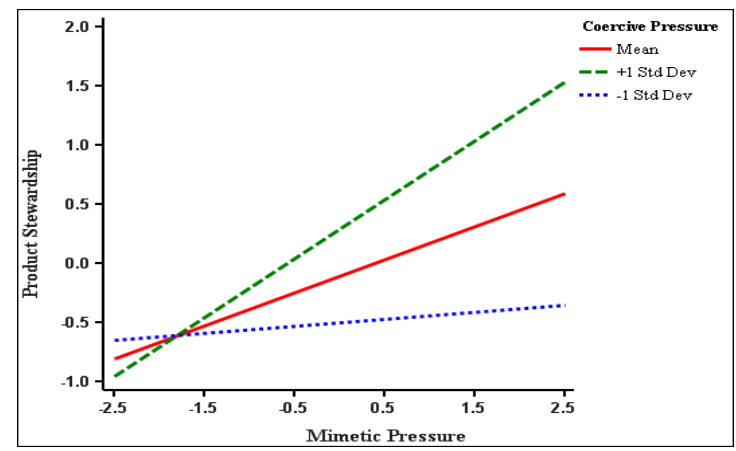

Figure 6. Interaction of Mimetic and Coercive Pressures (product stewardship)

\section{DISCUSSION}

This study examines institutional pressures that can motivate the adoption of green practices across organizations. Given the theoretical and empirical difficulty of differentiating the effects of mimetic and normative pressures, we focus on mimetic and coercive pressures and propose that both pressures are important factors that drive green IS \& IT practices. Adoption of general rather than industryspecific IS \& IT is of interest. We control for the effects of certain organizational attributes such as industry and revenue. We consider frequency- and outcome-based imitations as two important mechanisms of mimetic isomorphism. The extent to which other organizations have adopted green IS \& IT and the perceived success of their adoptions serve as valid proxy indicators of the mimetic pressure. Regulatory authorities and supply chain partners represent two important sources of coercive pressures.

Our analysis provides strong support for the main effects of mimetic and coercive pressures. The hypothesized complementary relationship between the two constructs receives partial support, being significant only in the product stewardship model. One explanation for the partial support for the complementary relationship between mimetic and coercive pressures may be that the reliance on supply chain partners and the lack of regulatory guidance in product stewardship practices present high uncertainty so that organizations take extra precaution in adoption decision-making. 
According to our analysis, outcome-based imitation consistently represents a significant source of mimetic pressures across the models of pollution prevention, product stewardship and sustainable development, while frequency-based imitation is consistently insignificant. This suggests organizations cautiously adopt green IS \& IT: the sheer number of adopters is not strong enough to reduce the uncertainty associated with green practices. Rather, the perceived favorable outcomes provide a more convincing rationale for adoption.

In contrast to the consistent pattern of mimetic pressures, different indicators of coercive pressures turn out to be significant in different models. Regulations are a significant source of coercive pressures only in models predicting pollution prevention and sustainable development practices. This reflects the effectiveness of regulatory efforts in guiding green behaviors across organizations, especially when such behaviors have an organization-wide, as opposed to supply-chain-wide, impact.

Pressures from supply chain partners, rather than regulations, turn out to be significant in the model of product stewardship. On the one hand, this suggests a lag in regulatory efforts to motivate a fulllifecycle eco-friendliness. On the other hand, the significance of coercive pressures from supply chain reflects the supply-chain-dependent nature of practices oriented towards product stewardship. Product stewardship emphasizes the full lifecycle of a product, striving to turn the traditional cradle-to-grave production into cradle-to-cradle eco-design that builds upon the collaborative agreements among supply chain partners. It calls for a mindset shift from a partial-lifecycle to a full-lifecycle perspective. Overall optimization does not necessarily mean local optimization. As stakeholders become salient at different stages of a product lifecycle, they tend to maximize financial gains during the part of product lifecycle that matters to their financial performance rather than seeking a fulllifecycle optimization. For example, manufacturers are the dominant stakeholders during the production stage. Obtaining materials, manufacturing products, and distributing products through retail channels are of immediate concern to manufacturers. Therefore, they aim to optimize those activities to increase financial gains during the production stage. Manufacturers are seldom interested in how individual consumers deal with the products at the end of their lifecycle, especially in financial terms. Likewise, consumers tend to care more about the price and performance of a product than about how it is produced and how raw materials are obtained. Creating regulations that effectively drive collective efforts across supply chain can be a challenging task for regulatory authorities.

Given the relatively small sample size (i.e., 75 responses) and relatively large presence of US-based organizations (i.e., $33 \%$ of the responding organizations based in US), we conducted additional analysis. First, we calculated post-hoc statistical power for our models, all of which turned out to have sufficient power (over 0.99). Second, we analyzed alternative models by including moderating effects to assess whether being based in US affects the observed relationships. We did not detect any significant differences (at 0.05 ) between US-based organizations and non-US-based ones in the hypothesized relationships.

\section{Beyond the Adoption of Green IS/IT: Studying the Eco-Goals}

This study has focused on the adoption of particular IS \& IT related practices. More importantly, we believe, is the adoption of a mindset focused on the implementation of sustainable organizational practices. Solving global climate change requires a wholehearted acceptance of the general principles of ecological change, rather than just adopting specific practices. We need general executives who think green as well as acting green. We need IS executives who envisage how IS can create a sustainable corporation and can move beyond greening the data center or installing power monitoring for personal computers. Institutional theory and the natural-resource-based view of the firm are not the only theoretical lenses that can be used to examine green IS \& IT. Adoption of the three eco-goals 
(eco-efficiency, eco-equity, and eco-effectiveness) identified in the sustainability literature (Dyllick et al. 2002) can be used as a framework for understanding green IS \& IT.

Eco-efficiency is "the delivery of competitively-priced goods and services that satisfy human needs and bring quality of life, while progressively reducing ecological impacts and resource intensity throughout the life-cycle to a level at least in line with the earth's carrying capacity" (DeSimone et al. 1997). Eco-efficiency is aligned with organizational efficiency and profitability. Reducing energy consumption and resource usage is clearly also a way of cutting costs and improving revenues. Thus, we would expect institutional theory to explain the adoption of eco-efficiency, because although it aligns with economic performance, there is also strong social pressure for economic efficiency in liberal democracies. It is part of the social fabric to expect efficiency from economic actors. The pursuit of eco-efficiency goals is not likely to change current institutional forces on IS leaders.

Eco-equity refers to the "equity between peoples and generations and, in particular, the equal rights of all peoples to environmental resources" (Gray et al. 2000). Implicitly, sustainability requires a fair distribution of resources both within and across generations and thus eco-equity is a core principle for those advocating sustainability. Eco-equity is driven by social pressures and may be misaligned with short or even medium term eco-efficiency goals. Eco-equity focuses on the current generation's social responsibility for those who inherit what it leaves in place. In the pursuit of economic goals, many societies would appear to be willing to let their descendants bear the consequences of excessive current consumption of scarce resources. In order to understand what adoption of eco-equity principles means for IS leaders, we need to identify the consequences of seeking eco-equity and the impact on our field.

The concept of eco-effectiveness was introduced late last century (McDonough et al. 1998) without a clear statement of its meaning. The coiners explained that "Our concept of eco-effectiveness means working on the right things - on the right products and services and systems - instead of making the wrong things less bad" (McDonough et al. 2002). The parallels to Drucker's $(1954 ; 2006)$ life-long concern with distinguishing between efficiency (doing things right) and effectiveness (doing the right things) are evident. Achieving an eco-effective civilization, which is the only long-term goal we can sensibly pursue for the survival of our species, requires a radical transformation of current thinking on most matters (McDonough et al. 2002), including IS (Watson et al. 2010)

We contend that organizations need to move beyond eco-efficiency. Sustainability, restoration, and regeneration should be the prevailing organizational aspirations (McDonough et al. 2002). In particular for our domain, we need to understand what these goals mean for IS leaders. For perhaps the last half century, IS leaders have managed the technology that has transformed business and society (e.g., networks, relational database, programming languages, graphical user interface, and so forth). We need to translate these goals of sustainability, restoration, and regeneration into IS actions and unleash the transformative power of IS to promote sustainability. Rather than applying theoretical perspectives reactively, as most social scientists do and as we have done in this study, we need to become solution scientists and apply theories proactively to accelerate the adoption of highly desirable organizational traits and IS practices for eco-effectiveness.

\section{Contributions and Implications for Research and Practice}

This study contributes to research and practice in several ways. The contribution to research is threepronged. First, it represents one of the few studies focusing on the role played by IS \& IT in green practices. The heightened importance of ecological sustainability has generated a body of research on green practices. However, IS \& IT have been a missing piece of the eco-sustainability puzzle. By drawing upon the natural-resource-based view of the firm, we identify three types of IS \& IT-based green practices. We also make an important distinction between IS and IT in driving ecological sustainability. Second, the research contributes to the literature of institutional theory by examining 
the interaction between institutional forces. Although such interaction has been theoretically recognized (Delmas and Toffel, 2004), there is a paucity of empirical research on it. In particular, this study provides empirical support for the complementary effects between mimetic and coercive pressures in driving the adoption of IS \& IT-based product stewardship by organizations. Third, this study also enriches the research on green practices by assessing organizational action on adopting a multitude of green practices. A wide variety of practices can better capture the eco-friendliness of an organization. In other work, we have introduced the idea of a new IS subfield, Energy Informatics (Watson et al. 2010), to focus on using IS \& IT to improve energy efficiency. It is important that IS scholars start working in this area. We need to make a contribution, and we believe a good starting point is to discover what causes the adoption of the fundamentally different types of green behaviors.

The research model and the hypotheses developed in this study provide avenues for future research. First, by examining a multitude of generic IS \& IT-based green practices, we have embarked on a study across various industries. Future studies can take a finely grained approach by focusing on a particular industry. Thus, the findings based on industry-specific green IS \& IT may provide more insights in industrial heterogeneity regarding the adoption of green practices. Alternatively, future research can also explore emerging green IS \& IT practices, which may not exist or gain prevalence when this study was conducted. The advancement of IS and IT, coupled with the growth of institutional pressures, may further change the industrial landscape and give rise to new practices across organizations. Therefore, revisiting the list of green IS \& IT practices identified in this study is important for keeping our understanding of the field current. We should expect more IS practices to emerge in the near future as attention has been mainly focused on IT. To some extent greening IT has not required much imagination - cut energy use - and IS-driven greening will require greater creativity and could produce a greater variety of practices. Second, given the cross-sectional nature of research design, this study focuses on the synchronic effects of the institutional pressures. To complement the findings yielded in this study, future research can take a longitudinal approach to demonstrate the interactive operation of the institutional forces over time, and thereby account for the diachronic effects. Additionally, our understanding of green IS \& IT in this study is built upon a small sample size (75 organizations). A future study based on an extended sample can be conducted to refine our understanding of this increasingly important phenomenon. Additionally, the majority of the respondents were from high per capita income, liberal democracies. Given that China is now the major contributor to green house gases, we need to replicate this study in China, which has a different culture, lower per capita incomes, and is a command economy.

Our study has important implications for practitioners. First, the outcome-based mimetic isomorphism is an important determinant of organizational adoption of green IS \& IT. Due to the inherent uncertainty of the outcomes of green practices, making successful adoptions known to potential adopters will motivate their mind-set shift and provide effective guidance in their decision-makings. Thus, part of general research in this area is to publish case studies on leading green IS practices (Watson et al. 2009b) and a chapter for introductory IS classes (Watson et al. 2008). Second, it highlights the importance of the complementary effects between mimetic and coercive pressures. The complementary effects between the two kinds of pressure may inform regulatory authorities in developing effective interventions in driving the diffusion of green IS \& IT across organizations. Finally, this study also brings to the attention of organizations and regulatory bodies the separate roles played by IS and IT in the pursuit of ecological sustainability. This careful differentiation helps organizations to find the right positions for IS and IT in their green business strategies. 


\section{REFERENCES}

American Psychological Association Online (2009). Peer pressure best motivator when it comes to energy saving, psychologists tell House panel. Accessed last October 2009 at http://www.apa.org/releases/peerpressure.html.

Banker, R.D., and Kauffman, R.J. (1988). Strategic contributions of information technology: an empirical study of ATM networks. Proceedings of The Ninth International Conference on Information Systems, Minneapolis, MN, pp. 141-150.

Bonifant, B.C., and Ratcliffe, I. (1994). Competitive Implications of Environmental Regulation in the Pulp and Paper Industry. Working paper, Management Institute for Environment and Business, Washington, D.C., 1994.

Boudreau, M., Watson, R.T., and Chen, A. (2008). From Green IT to Green IS. Cutter Benchmark Review, Vol. 8(5) 2008, pp. 5-11.

Burns, L., and Wholey, D. (1993). Adoption and abandonment of matrix management programs: Effects of organizational characteristics and interorganizational networks. Academy of Management Journal, pp. 106-138.

Campbell, J. (2007). Why would corporations behave in socially responsible ways? An institutional theory of corporate social responsibility. Academy of Management Review, Vol. 32(3), pp. 946-967.

Carey, J. (2009). The tug-of-war over cap and trade. BusinessWeek, The McGraw-Hill Companies, pp. 20-22.

Chen, A., Boudreau, M., and Watson, R. (2008). Information systems and ecological sustainability," Journal of Systems and Information Technology, Vol. 10, pp. 186-201.

Cheung, S., Chan, D., and Wong, Z. (1999). Reexamining the theory of planned behavior in understanding wastepaper recycling. Environment and Behavior, Vol. 31(5), pp. 587-612.

Clemens, B., and Douglas, T. (2006). Does coercion drive firms to adopt 'voluntary' green initiatives? Relationships among coercion, superior firm resources, and voluntary green initiatives. Journal of Business Research, Vol. 59(4), pp. 483-491.

Delmas, M., and Terlaak, A. (2001). A framework for analyzing environmental voluntary agreements. California Management Review, Vol. 43(3), pp. 44-63.

Delmas, M., and Toffel, M. (2004). Stakeholders and environmental management practices: an institutional framework. Business Strategy and the Environment, Vol. 13(4), pp. 209-222.

DeSimone, L.D., and Popoff, F. (2000). Eco-efficiency : the business link to sustainable development MIT Press, Cambridge, Mass.

Diamantopoulos, A., and Siguaw, J. (2006). Formative versus reflective indicators in organizational measure development: a comparison and empirical illustration. British Journal of Management, Vol. 17(4), pp. 263-282.

Diamantopoulos, A., and Winklhofer, H. (2001). Index construction with formative indicators: an alternative to scale development. Journal of Marketing Research, pp. 269-277.

DiMaggio, P.J., and Powell, W.W. (1983). The Iron Cage Revisited: Institutional Isomorphism and Collective Rationality in Organizational Fields. American Sociological Review, Vol. 48(2), pp. 147-160.

Drucker, P.F. (1954). The practice of management, Harper, New York, pp. 404.

Drucker, P.F. (2006). What executives should remember. Harvard Business Review, Vol. 84(2), pp. 144-153. 
Dyllick, T., and Hockerts, K. (2002). Beyond the business case for corporate sustainability," Business Strategy and the Environment, Vol. 11(2), pp. 130-141.

Frenken, K., Hekkert, M., and Godfroij, P. (2004). R\&D portfolios in environmentally friendly automotive propulsion: variety, competition and policy implications. Technological Forecasting \& Social Change, Vol. 71(5), pp. 485-507.

Ghose, A., Hoesch-Klohe, K., Hinsche, L., and Le, L.-S. (2009). Green Business Process Management: A Research Agenda. Australian Journal of Information Systems, Vol. 16(2), pp. 103-117.

Ginsberg, A., and Buchholtz, A. (1990). Converting to for-profit status: corporate responsiveness to radical change. Academy of Management Journal, pp. 445-477.

González, P.d.R. (2005). Analysing the factors influencing clean technology adoption: a study of the Spanish pulp and paper industry. Business Strategy and the Environment, Vol. 14(1), pp. 2037.

Gray, R., and Bebbington, K. (2000). Environmental accounting, managerialism and sustainability: is the planet safe in the hands of business and accounting? Advances in Environmental Accounting and Management, Vol. 1(1), pp. 1-44.

Greening, D., and Gray, B. (1994). Testing a model of organizational response to social and political issues. Academy of Management Journal, pp. 467-498.

Hammer, M.C., and Champy, J. (1993). Reengineering the Corporation: A Manifesto for Business Revolution. Harper Business, New York.

Hart, S., and Ahuja, G. (1996). Does it pay to be green? An empirical examination of the relationship between emission reduction and firm performance. Business Strategy and the Environment, Vol. 5(1), pp. 30-37.

Hart, S.L. (1995). A Natural-Resource-Based View of the Firm. Academy of Management Review, Vol. 20(4), pp. 986-1014.

Haunschild, P., and Miner, A. (1997). Modes of Interorganizational Imitation: The Effects of Outcome Salience and Uncertainty. Administrative Science Quarterly, Vol. 42(3), pp. 472-500.

Huff, S., and Munro, M. (1985). Information technology assessment and adoption: a field study. MIS Quarterly, pp. 327-340.

Iacovou, C., Benbasat, I., and Dexter, A. (1995). Electronic data interchange and small organizations: adoption and impact of technology. MIS Quarterly, pp. 465-485.

Jennings, P.D., and Zandbergen, P.A. (1995). Ecologically Sustainable Organizations: An Institutional Approach. Academy of Management Review, Vol. 20(4), pp. 1015-1052.

Kilbourne, W., Beckmann, S., and Thelen, E. (2002). The role of the dominant social paradigm in environmental attitudes: a multinational examination. Journal of Business Research, Vol. 55(3), pp. 193-204.

Knoke, D. (1982). The spread of municipal reform: Temporal, spatial, and social dynamics. American Journal of Sociology, pp. 1314-1339.

Kuo, B., and Dick, G. (2009). The Greening of Organisational IT: What Makes a Difference? Australian Journal of Information Systems, Vol. 16(2), pp. 81-92.

Lampe, M., Ellis, S. R., and Drummond, C. K. (1991). What companies are doing to meet environmental protection responsibilities: Balancing legal, ethical, and profit concerns. Proceedings of the International Association for Business and Society, pp. 527-537.

Lee, K., and Pennings, J.M. (2002). Mimicry and the Market: Adoption of a New Organizational Form. Academy of Management Journal, Vol. 45(1), pp. 144-162. 
Lewin, K. (1947). Frontiers in group dynamics. Human Relations, pp. 5-41.

Liang, H., Saraf, N., Hu, Q., and Xue, Y. (2007). Assimilation of enterprise systems: The effect of institutional pressures and the mediating role of top management. MIS Quarterly, Vol. 31(1), pp. 59.

Lu, J. (2002). Intra-and Inter-Organizational Imitative Behavior: Institutional Influences on Japanese Firms' Entry Mode Choice. Journal of International Business Studies, Vol. 33(1), pp 19-38.

March, J. (1981). Decisions in organizations and theories of choice. In A.H. Van de Ven and W.F. Joyce (eds.) Perspectives on organization design and behavior, Wiley, NY, pp. 205-244.

McDonough, W., and Braungart, M. (1998). The NEXT industrial revolution. In The Atlantic Monthly.

McDonough, W., and Braungart, M. (2002). Cradle to cradle: Remaking the way we make things. North Point Press.

Meyer, J., and Rowan, B. (1977). Institutionalized organizations: Formal structure as myth and ceremony. American Journal of Sociology, Vol. 83(2), pp. 340-363.

Meyer, J., and Scott, W. (1992). Organizational environments. Sage Publications, Newbury Park, CA.

Mezias, S. (1990). An institutional model of organizational practice: Financial reporting at the Fortune 200. Administrative Science Quarterly, pp. 431-457.

Mitchell, R., Agle, B., and Wood, D. (1997). Toward a theory of stakeholder identification and salience: Defining the principle of who and what really counts. Academy of Management Review, pp. 853-886.

Mizruchi, M., and Fein, L. (1999). The Social Construction of Organizational Knowledge: A Study of the Uses of Coercive, Mimetic, and Normative Isomorphism. Administrative Science Quarterly, Vol. 44(4), pp. 653-683.

Molla, A. (2008). GITAM: A Model for the Adoption of Green IT. Proceedings of the 19th Australasian Conference on Information Systems, Christchurch, New Zealand, pp. 658-668.

Molla, A., Cooper, V., Deng, H., and Lukaitis, S. (2009a). A Preliminary Report on Green IT Attitude and Actions among Australian IT Professionals. Working paper, School of Business Information Technology, RMIT University, Melbourne, Australia, pp. 1-13.

Molla, A., Pittayachawan, S., and Corbitt, B. (2009b). Green IT Diffusion: An International Comparison. Working paper, School of Business Information Technology, RMIT University, Melbourne, Australia.

Olson, E. (2008). Creating an enterprise-level "green" strategy. Journal of Business Strategy, Vol. 29(2), pp. 22-30.

Orlikowski, W., and Barley, S. (2001). Technology and institutions: what can research on information technology and research on organizations learn from each other? MIS Quarterly, pp. 145-165.

Perrow, C. (1986). Complex organizations: A critical essay. Random House Trade.

Petter, S., Straub, D., and Rai, A. (2007). Specifying formative constructs in information systems research. MIS Quarterly, Vol. 31(4), pp. 623-656.

Pfeffer, J., and Salancik, G. (1978). The external control of organizations: A resource dependence perspective. Harper \& Row, New York.

Porter, M.E., and van der Linde, C. (1995). Green and Competitive: Ending the Stalemate. Harvard Business Review, Vol. 73(5), pp. 120-133.

Riggins, F., Kriebel, C., and Mukhopadhyay, T. (1994). The growth of interorganizational systems in the presence of network externalities. Management Science, pp. 984-998. 
Rooney, C. (1993). Economics of Pollution Prevention: How Waste Reduction Pays. Pollution Prevention Review, Vol. 3(Summer), pp. 261-276.

Rowan, B. (1982). Organizational structure and the institutional environment: The case of public schools. Administrative Science Quarterly, pp. 259-279.

Roy, C., and Séguin, F. (2000). The institutionalization of efficiency-oriented approaches for public service improvement. Public Productivity \& Management Review, pp. 449-468.

Scott, R. (2003). Organizations: Rational, Natural, and Open Systems (5th ed.). Prentice Hall, Upper Saddle River, NJ.

Shrivastava, P., and Hart, S. (1992). Greening organizations. Proceedings of the Annual Meeting of Academy of Management, Las Vegas, NV, pp. 185-189.

Shrivastava, P., and Hart, S. (1995). Creating sustainable corporations. Business Strategy and the Environment, Vol. 4(3), pp. 154-165.

Smart, B. (1992). Beyond compliance: A new industry view of the environment. World Resources Institute, Washington, DC.

Teo, H., Wei, K., and Benbasat, I. (2003). Predicting intention to adopt interorganizational linkages: An institutional perspective. MIS Quarterly, pp. 19-49.

Tingling, P., and Parent, M. (2002). Mimetic isomorphism and technology evaluation: does imitation transcend judgment? Journal of the Association for Information Systems, Vol. 3(1), pp. 113143.

Tolbert, P., and Zucker, L. (1983). Institutional sources of change in the formal structure of organizations: The diffusion of civil service reform, 1880-1935. Administrative Science Quarterly, Vol. 28(1), pp. 22-39.

Velasquez, M., and Rostankowski, C. (1985). Ethics: theory and practice. Prentice-Hall, Englewood Cliffs, NJ.

Watson, R., Aronson, J., Donnellan, B., and Desautels, P. (2009a). Energy + Information < Energy. 15th Americas Conference on Information Systems, San Francisco, CA, USA, pp. 448.

Watson, R. T., Boudreau, M.-C., Chen, A., and Huber, M. (2009b). Green IS: Building sustainable business practices. The Global Text Project, Athens, GA, USA, http://globaltext.terry.uga.edu/books\#greenis.

Watson, R. T., Boudreau, M.-C., Li, S. and Levis, J., (2009c). UPS: En route to Energy Informatics. Working paper, University of Georgia, GA.

Watson, R. T., Boudreau, M.-C., Chen, A. (2010). Information Systems and Environmentally Sustainable Development: Energy Informatics and New Directions for the IS community. MIS Quarterly, Vol. 34(1), pp. 23-38.

Yi, L., and Thomas, H. (2007). A review of research on the environmental impact of e-business and ICT. Environment International, Vol. 33(6), pp. 841-849.

Zucker, L. (1977). The role of institutionalization in cultural persistence. American Sociological Review, pp. 726-743.

Zucker, L. (1987). Institutional theories of organization. Annual Review of Sociology, Vol. 13(1), pp. 443-464. 
APPENDIX A: CORRELATION MATRIX

\begin{tabular}{|c|c|c|c|c|c|c|c|c|c|c|c|c|c|}
\hline & $\begin{array}{l}\text { Mean } \\
\text { (Std } \\
\text { Dev) }\end{array}$ & 1 & 2 & 3 & 4 & 5 & 6 & 7 & 8 & 9 & 10 & 11 & 12 \\
\hline $\begin{array}{l}\text { 1.Frequency- } \\
\text { Based }\end{array}$ & $\begin{array}{l}1.30 \\
(1.21)\end{array}$ & 1.000 & & & & & & & & & & & \\
\hline $\begin{array}{l}\text { 2.Outcome- } \\
\text { Based }\end{array}$ & $\begin{array}{l}3.16 \\
(0.77)\end{array}$ & 0.204 & 1.000 & & & & & & & & & & \\
\hline $\begin{array}{l}\text { 3.Imposition- } \\
\text { Based }\end{array}$ & $\begin{array}{l}3.32 \\
(1.25)\end{array}$ & $\overline{-}-$ & $\begin{array}{c}0.454 \\
* *\end{array}$ & 1.000 & & & & & & & & & \\
\hline $\begin{array}{l}\text { 4.Inducement- } \\
\text { Based }\end{array}$ & $\begin{array}{l}2.70 \\
(1.05)\end{array}$ & 0.117 & $\begin{array}{l}0.447 \\
* *\end{array}$ & $\begin{array}{c}0.575 \\
* *\end{array}$ & 1.000 & & & & & & & & \\
\hline 5.PolPre_prob & $\begin{array}{l}3.84 \\
(1.46)\end{array}$ & 0.108 & $\begin{array}{l}0.485 \\
* *\end{array}$ & $\begin{array}{c}0.390 \\
* *\end{array}$ & $\begin{array}{l}0.320 \\
* *\end{array}$ & 1.000 & & & & & & & \\
\hline 6.PolPre_solu & $\begin{array}{l}4.35 \\
(1.87)\end{array}$ & 0.225 & $\begin{array}{c}0.367 \\
* *\end{array}$ & $\begin{array}{c}0.384 \\
* *\end{array}$ & $\begin{array}{c}0.386 \\
* *\end{array}$ & $\begin{array}{c}0.376 \\
* *\end{array}$ & 1.000 & & & & & & \\
\hline 7.ProSte_prob & $\begin{array}{l}3.64 \\
(1.40)\end{array}$ & 0.133 & $\begin{array}{c}0.387 \\
* *\end{array}$ & $\begin{array}{c}0.405 \\
* *\end{array}$ & $\begin{array}{c}0.333 \\
* *\end{array}$ & $\begin{array}{c}0.579 \\
* *\end{array}$ & $\begin{array}{c}0.486 \\
* *\end{array}$ & 1.000 & & & & & \\
\hline 8.ProSte_solu & $\begin{array}{l}2.93 \\
(1.38)\end{array}$ & $\begin{array}{c}0.268 \\
*\end{array}$ & $\begin{array}{c}0.365 \\
* *\end{array}$ & $\begin{array}{c}0.302 \\
* *\end{array}$ & $\begin{array}{l}0.442 \\
* *\end{array}$ & $\begin{array}{l}0.518 \\
* *\end{array}$ & $\begin{array}{l}0.690 \\
* *\end{array}$ & $\begin{array}{c}0.540 \\
* *\end{array}$ & 1.000 & & & & \\
\hline 9.SusDev_prob & $\begin{array}{l}1.52 \\
(0.76)\end{array}$ & 0.181 & $\begin{array}{c}0.230 \\
*\end{array}$ & $\begin{array}{l}0.291 \\
*\end{array}$ & 0.13 & $\begin{array}{c}0.356 \\
* *\end{array}$ & $\begin{array}{l}0.584 \\
* *\end{array}$ & $\begin{array}{c}0.496 \\
* *\end{array}$ & $\begin{array}{l}0.408 \\
* *\end{array}$ & 1.000 & & & \\
\hline 10.SusDev_solu & $\begin{array}{l}6.41 \\
(1.98)\end{array}$ & 0.058 & $\begin{array}{l}0.460 \\
* *\end{array}$ & $\begin{array}{c}0.403 \\
* *\end{array}$ & $\begin{array}{c}0.268 \\
*\end{array}$ & $\begin{array}{c}0.569 \\
* *\end{array}$ & $\begin{array}{c}0.439 \\
* *\end{array}$ & $\begin{array}{c}0.575 \\
* *\end{array}$ & $\begin{array}{c}0.584 \\
* *\end{array}$ & $\begin{array}{c}0.340 \\
* *\end{array}$ & 1.000 & & \\
\hline 11.Industry & $\begin{array}{l}11.72 \\
(6.18)\end{array}$ & -0.15 & 0.088 & 0.127 & 0.109 & -0.03 & -0.08 & 0.033 & -0.06 & -0.11 & -0.03 & 1.000 & \\
\hline 12.Revenue & $\begin{array}{l}3.60 \\
(2.10)\end{array}$ & 0.075 & 0.004 & 0.06 & 0.043 & 0.151 & 0.04 & -0.00 & 0.084 & 0.047 & 0.05 & 0.156 & 1.000 \\
\hline
\end{tabular}

*. Correlation is significant at the 0.05 level (2-tailed).

**. Correlation is significant at the 0.01 level (2-tailed).

The AVE values of frequency-based imitation are $0.839,0.843$, and 0.814 for the models of pollution prevention, product stewardship, and sustainable development, respectively; the AVE values of outcome-based imitation for the three models are 0.693, 0.691, and 0.685, respectively; and the AVE values of inducement-based coercion for the three models are $0.832,0.834$, and 0.828 , respectively. 